\title{
Transferability of heterologous microsatellite primers in Brycon gouldingi
}

\author{
Felipe Pinheiro de Souza ${ }^{1^{*}}$ (\%) Ed Christian Suzuki de Lima ${ }^{1}$ \\ Natalia Gonçalves Leite ${ }^{1}$ Angela Maria Urrea-Rojas' ${ }^{1}$ Andrei Lincoln Yamachita ${ }^{1}$ \\ Victor César Freitas Pandolfi ${ }^{1}$ Nelson Mauricio Lopera-Barrero ${ }^{1}$
}

\footnotetext{
${ }^{1}$ Programa de Pós-Graduação em Ciência Animal, Departamento de Zootecnia, Universidade Estadual de Londrina (UEL), 86057-970, Londrina, PR, Brasil. E-mail: felipeps1991@gmail.com. *Corresponding author.
}

\begin{abstract}
Brycon gouldingi is a species of neotropical fish of socioeconomic and environmental importance in the Tocantins-Araguaia Basin. Genetic studies on this species are still limited, making it difficult to evaluate the population structure and genetic diversity in natural and captive stocks. Here, we aimed to evaluate the transferability of heterologous microsatellite primers in B. gouldingi. A total of 30 primers for eight species were evaluated: Brycon hilarii, Brycon opalinus, Brycon cephalus, Brycon orbignyanus, Prochilodus lineatus, Prochilodus argenteus, Piaractus mesopotamicus, and Colossoma macropomum. The primers that showed the best amplification patterns were applied to 20 specimens of B. gouldingi, and their genetic parameters were assessed. Among the 30 primers, seven showed satisfactory transferability, six of which belonged to the genus Brycon: Bh13 (B. hilarii), BoM5, BoM13 (B. opalinus), Borg9, Borg13, and Borg59 (B. orbignyanus), and one belonged to P. argenteus (Par80). The primers for the other species tested showed non-specificity or monomorphism; and were therefore, excluded from the analyses. The number of alleles ranged between two (Borg13 and Borg59) and three (Bh13, BoM5, BoM13, Borg9 and Par80), with sizes varying between 103 bp (BoM5) and 430 bp (Borg9). Four primers showed evidence of null alleles (BoM13, Borg9, Borg13, and Par80), which could probably be attributed to the respective Hardy-Weinberg deviation. Thus, seven primers were validated for crossamplification in B. gouldingi, which may be used in future studies involving this species.
\end{abstract}

Key words: conservation, cross-amplification, molecular markers, SSR.

Transferibilidade de primers microssatélites heterólogos em Brycon gouldingi

RESUMO: Brycon gouldingi é uma espécie de peixe neotropical com importância socioeconômica e ambiental na Bacia do TocantinsAraguaia. Estudos genéticos nessa espécie ainda são escassos, dificultando o conhecimento sobre a estrutura populacional e a diversidade genética nos estoques naturais e em cativeiro. O objetivo do presente estudo foi avaliar a transferibilidade de primers microssatélites heterólogos em B. gouldingi. Foram avaliados um total de 30 primers de oito espécies: Brycon hilarii, Brycon opalinus, Brycon cephalus, Brycon orbignyanus, Prochilodus lineatus, Prochilodus argenteus, Piaractus mesopotamicus e Colossoma macropomum. Os primers que demonstraram melhores padrões de amplificação foram aplicados em 20 espécimes de B. gouldingi para os cálculos dos parâmetros genéticos. Sete dos 30 primers apresentaram resultados satisfatórios de transferibilidade, sendo seis oriundos do gênero Brycon: Bh13 (B. hilarii), BoM5, BoM13 (B. opalinus), Borg9, Borg13 e Borg59 (B. orbignyanus), e um oriundo de P. argenteus (Par80). Os primer das outras espécies testados mostraram inespecificidade ou monomorfismo, sendo excluídos das análises. O número de alelos variou de dois (Borg13 e Borg59) a três (Bh13, BoM5, BoM13, Borg9 e Par80), com tamanhos entre 103 pb (BoM5) e 430 pb (Borg9). Quatro primers apresentaram evidências de alelos nulos (BoM13, Borg9, Borg13 e Par80), o que provavelmente inferiu sobre o desvio de Hardy-Weinberg nos mesmos. Concluindo, sete primers foram validados para a amplificação cruzada em B. gouldingi e poderão ser utilizados em futuros estudos com essa espécie. Palavras-chave: amplificação cruzada, conservação, Marcadores moleculares, SSR.

\section{INTRODUCTION}

Piabanha (Brycon gouldingi) is an endemic fish from the Araguaia-Tocantins basin, inhabiting tropical benthic-pelagic freshwater environments, and is popular among the fishing communities for its nutritional characteristics and possible use in fish farming (LIMA, 2004). Despite its regional importance and characteristics suitable for captive breeding, few studies have assessed its environmental, ecological (ALBRECHT et al., 2009), taxonomic (LIMA, 2017), morphological, developmental (FAUSTINO et al., 2010, 2015), and genetic (ANTUNES et al., 2010) characteristics.

Genetic studies have revealed important knowledge allowing for the development of 
management and conservation strategies. Among the tools used are molecular markers, such as microsatellite markers due to its high polymorphism, distribution along the genome, and its co-dominant characteristic, allowing for a wide spectrum of genetic information to be obtained (ABDUL-MUNEER et al., 2014; VIEIRA et al., 2016).

The use of microsatellites requires specific primers for each species, which are currently not available for B. gouldingi. However, several studies have shown that pairs of primers designed for one species can be used for other species of the same genus (OLIVEIRA et al., 2006; LOPERA-BARRERO et al., 2016a; CASTRO et al., 2017), which are commonly known as heterologous primers. Therefore, studies aimed to characterize these primers required for genetic studies of this species.

This study aimed to verify the crossamplification of microsatellite markers of eight species of fish: Brycon opalinus, Brycon hilarii, Brycon cephalus, Brycon orbignyanus, Prochilodus argenteus, Prochilodus lineatus, Piaractus mesopotamicus and Colossoma macropomum in $B$. gouldingi, and to evaluate the genetic diversity of 20 specimens collected in the Araguaia River.

\section{MATERIALS AND METHODS}

Caudal fin fragments (approximately $0.5 \mathrm{~cm}^{2}$ ) were collected from wild specimens of Brycon gouldingi from the Araguaia River, Mato Grosso, Brazil. Samples were kept in $1.5 \mathrm{~mL}$ microtubes containing $70 \%$ alcohol until arrival at the laboratory of the Aquaculture and Genetics Research Center (NEPAG), State University of Londrina (UEL). The research was approved by the ethics committee on the use of animals at UEL (OF.CIR.99/2017).

DNA extraction from the fins was performed with a $\mathrm{NaCl}$ protocol as described previously by LOPERA-BARRERO et al. (2008). The DNA concentration was measured by spectrophotometry, and the samples were diluted to a final volume of $30 \mathrm{ng} / \mu \mathrm{L}$. The DNA integrity was confirmed on a $1 \%$ agarose gel stained with SYBR Safe ${ }^{\mathrm{TM}}$ DNA (Invitrogen). Electrophoresis was performed in $1 \mathrm{X}$ TBE buffer for $1 \mathrm{~h}$ at $100 \mathrm{~V}$. The gel was observed with the aid of a UV light-emitter and photos were captured by a photo-documentation system.

Thirty microsatellite primers were used for the cross-amplification tests, 13 of which were for the genus Brycon: Bh5, Bh6, Bh8, Bh13, Bh16 (B. hilarii) (SANCHES \& GALETI Jr, 2006); Bc48-10 (B. cephalus) (BARROSO, 2003); BoM5, BoM13
(B. opalinus) (BARROSO et al., 2003) and Borg9, Borg13, Borg56, Borg59, Borg65 (B. orbignyanus) (SOUZA et al., 2018). In addition, the following primers were tested: five primers for Piaractus mesopotamicus (Pme2, Pme4, Pme5, Pme20, Pme28) (CALCAGNOTTO et al. 2001), five primers for Colossoma macropomum (CmA8, CmA11, CmC8, CmD1, CmE3) (SANTOS et al., 2009), and seven primers for the genus Prochilodus, of which six were for P. argenteus (Par12, Par14, Par15, Par21, Par43, and Par80) (BARBOSA et al., 2006; BARBOSA et al., 2008) and one was for P. lineatus (Pli30) (YAZBECK \& KALAPOTHAKIS, 2007).

The amplification was performed in a final reaction volume of $15 \mu \mathrm{L}$ consisting of $1 \mathrm{X}$ Tris$\mathrm{KCl}$ buffer, $2.0 \mathrm{mM} \mathrm{MgCl} 2,0.4 \mu \mathrm{M}$ of each primer (forward and reverse), $0.4 \mathrm{mM}$ of each dNTP, a unit of Platinum Taq DNA Polymerase, and 30ng of DNA. First, the DNA was denatured at $94^{\circ} \mathrm{C}$ for $4 \mathrm{~min}$; followed by 30 cycles of $60 \mathrm{~s}$ of initial denaturation at $94^{\circ} \mathrm{C}, 45 \mathrm{~s}$ of annealing (variable temperature for each primer), and $60 \mathrm{~s}$ of extension at $72^{\circ} \mathrm{C}$, and a final extension at $72^{\circ} \mathrm{C}$ for $10 \mathrm{~min}$.

The amplified samples were subjected to $10 \%$ polyacrylamide gel electrophoresis, performed in $0.5 \mathrm{X}$ TBE buffer at $180 \mathrm{~V}$ and $250 \mathrm{~mA}$ for $8 \mathrm{~h}$. Next, nitrate staining was performed for the visualization of the microsatellite alleles. The gel was photodocumented and uploaded to the Adobe Photoshop CC program (64-bit version), where it was aligned, and the alleles were calculated using a 100bp DNA ladder. Primers that presented satisfactory amplification patterns were selected for the population analysis. After selection, 20 specimens of $B$. gouldingi were genotyped to calculate the genetic parameters. The amplification was performed as previously described, except for two primers for B. orbignyanus (Borg9 and Borg59), which presented a better band resolution after decreasing the number of cycles to 25 and the annealing time to $35 \mathrm{~s}$.

Number of alleles $(\mathrm{Na})$, effective number of alleles (Ne), observed heterozygosity (Ho), expected heterozygosity (He), and the HardyWeinberg equilibrium test (HW) were calculated for each locus by the GenAlex software version 6.5 (PEAKALL \& SMOUSE, 2012). Polymorphic information content (PIC) was calculated using the software Cervus version 3.0.7 (KALINOWSKI et al., 2007). The inbreeding coefficient $\left(F_{\text {IS }}\right)$ and the allelic richness $(\mathrm{Ra})$ were obtained on the FSTAT program version 2.9.3 (GOUDET, 2005). The presence of null alleles was tested on the Micro-Checker program version 2.2.3 (VAN OOSTERHOUT et al., 2004). 


\section{RESULTS}

After excluding the primers that were non-specific or monomorphic, seven primers showed satisfactory transferability results: one derived from B. hillari (Bh13), two from B. opalinus (BoM5 and BoM13), three from B. orbignyanus (Borg9, Borg13, and Borg59), and one from P. argenteus (Par80).

The number of alleles per locus ranged between two (Borg13 and Borg59) and three (Bh13, BoM5, BoM13, Borg9, and Par80), with sizes varying between 103 bp (BoM5) and 430 bp (Borg9) (Table 1). The Micro-checker software provided evidence of null alleles in the BoM13, Borg9, Borg13, and Par80 loci. The mean effective number of alleles $(\mathrm{Ne})$ and allelic richness $(\mathrm{Ra})$ were 1.704 and 2.601, respectively, ranging between 1.057 (Borg59) and 2.947 (BoM13), and 1.722 (Borg59) and 3.000 (BoM13), respectively. Low-frequency $(<0.100)$ alleles were observed in the Bh13 (162 and 182 bp), BoM5 (118 bp), Borg9 (395 bp), and Borg59 (250 bp) alleles (Table 1).

The expected heterozygosity $(\mathrm{He})$ values were higher than those observed (Ho) in four loci (BoM13, Borg9, Borg13, and Par80), which resulted in a heterozygous deficit as demonstrated by the inbreeding coefficient (Fis) (Table 2). Deviations from the Hardy-Weinberg (HW) equilibrium were significant $(<0.05)$ at the same loci, which was probably influenced by the heterozygous deficit or the presence of null alleles $(p<0.05)$, or a combination of both. Finally, the polymorphic information content
(PIC), which measures the informativeness of a molecular marker, ranged between 0.053 (Borg59) and 0.587 (BoM13) (Table 1).

\section{DISCUSSION}

The genus Brycon showed the highest transferability success, with six of the seven heterologous primers exhibiting satisfactory results. According to OLIVEIRA et al. (2006), the transferability between related species depends on the degree of conservation of the primer binding regions in the DNA, with evolutionarily closer species being more successful in cross-amplification. Recent studies have demonstrated this by evaluating the crossamplification of several species of the neotropical fish B. orbignyanus (CARMO et al., 2015; CASTRO et al., 2017), obtaining greater amplification predominantly among species of the same genus, which is consistent with the results of this study.

A recent study showed that the primers for $B$. opalinus and $B$. hilarii can be used in wild populations of $B$. orbignyanus (ASHIGAKA et al. 2015), exhibiting indices of Ho similar to those reported in the present study in individuals collected from the Uruguay and Paranapanema Rivers. Number of alleles per locus was also similar to that reported in the cross-amplification in B. orbignyanus at some loci such as BoM13 (CARMO et al., 2015; CASTRO et al. 2017), Bh13, BoM5, and Par80 (CASTRO et al., 2017). Contrarily, the number of alleles was lower relative to

Table 1 - Caracterization of Locus, Motif, Repetition, Species, Fragment size - bp (Frequency) and Polymorphic information content (PIC) of heterologous microsatellite primers.

\begin{tabular}{|c|c|c|c|c|c|}
\hline Locus & Motif & Repetition & Species & Fragmentsize - bp & PIC \\
\hline & & & & (Frequency) & \\
\hline \multirow[t]{2}{*}{ Bh13 } & Di- & $(\mathrm{AT})_{7}$ & B. hilarii & 162(0.088); 175(0.882); & 0.199 \\
\hline & & & & $182(0.03)$ & \\
\hline \multirow[t]{2}{*}{ BoM5 } & Comp & $(\mathrm{AC})_{4} \mathrm{~T}(\mathrm{AC})$ & B. opalinus & $103(0.147) ; 112(0.824)$ & 0.269 \\
\hline & & ${ }_{10} \mathrm{AT}(\mathrm{AC}){ }_{5}$ & & $118(0.029)$ & \\
\hline \multirow[t]{2}{*}{ BoM13 } & Di- & $(\mathrm{CT})_{11}$ & B. opalinus & 150(0.316); 175(0.289); & 0.587 \\
\hline & & & & $186(0.395)$ & \\
\hline \multirow[t]{2}{*}{ Borg9 } & Comp & $(\mathrm{TG})_{4}(\mathrm{TA})_{2} \mathrm{CTG}$ & B. orbignyanus & $395(0.079) ; 400(0.763)$ & 0.350 \\
\hline & & $(\mathrm{TA})_{2} \mathrm{CTG}(\mathrm{TA})_{2}$ & & $430(0.158)$ & \\
\hline Borg13 & Comp & $(\mathrm{CA})_{6} \mathrm{TT}(\mathrm{CA})_{3}(\mathrm{CT})_{2}$ & B. orbignyanus & $350(0.692) ; 355(0.308)$ & 0.335 \\
\hline \multirow[t]{2}{*}{ Borg59 } & Comp & $(\mathrm{CT})_{4} \mathrm{CC}(\mathrm{CT})_{5} \mathrm{TT}$ & B. orbignyanus & $220(0.972) ; 250(0.028)$ & 0.053 \\
\hline & & $(\mathrm{CT})_{5}(\mathrm{CA})_{9}(\mathrm{CT})_{3} \mathrm{~N}(\mathrm{CT})_{7}$ & & & \\
\hline \multirow[t]{2}{*}{ Par80 } & Di- & $(\mathrm{CT})_{37}$ & P. argenteus & $175(0.100) ; 180(0.700)$ & 0.410 \\
\hline & & & & $184(0.200)$ & \\
\hline
\end{tabular}

Di-: Dinucleotide; Comp: Complex; bp: base pair. 
Table 2 - Number of Alleles (Na), effective numbers of alleles (Ne), allele richness (Ra), observed heterozygosity (Ho), expected heterozygosity (He), Hardy-Weinberg equilibrium (p values) (HW) and inbreeding coefficient ( $\mathrm{F}_{\mathrm{IS}}$ ) per locus.

\begin{tabular}{lccccccc}
\hline Locus & $\mathrm{Na}$ & $\mathrm{Ne}$ & $\mathrm{Ra}$ & Ho & He & HW (p value) \\
\hline Bh13 & 3.000 & 1.270 & 2.755 & 0.235 & 0.213 & 0.960 & -0.076 \\
BoM5 & 3.000 & 1.427 & 2.765 & 0.294 & 0.299 & 0.103 & 0.048 \\
BoM13 & 3.000 & 2.947 & 3.000 & 0.263 & 0.661 & $0.000^{*}$ & 0.619 \\
Borg9 & 3.000 & 1.630 & 2.974 & 0.053 & 0.386 & $0.000^{*}$ \\
Borg13 & 2.000 & 1.742 & 2.000 & 0.000 & 0.426 & $0.000^{*}$ & 0.871 \\
Borg59 & 2.000 & 1.057 & 1.722 & 0.056 & 0.054 & 0.904 & 0.000 \\
Par80 & 3.000 & 1.852 & 2.989 & 0.200 & 0.460 & $0.000^{*}$ \\
Mean & 2.714 & 1.703 & 2.600 & 0.157 & 0.357 & 0.582 \\
\hline
\end{tabular}

*Significant at $\mathrm{p}<0.05$

those reported from studies that used species-specific primers of B. opalinus and B. hilarii (BARROSO et al., 2003; BIGNARDI et al., 2016). Other studies have demonstrated that the genus Prochilodus also has a high plasticity of microsatellite loci transfer (BARBOSA et al., 2008; LOPERA-BARRERO et al., 2016b), even among different genera, as shown by CASTRO et al. (2017), who observed that Par80, the same loci amplified for B. gouldingi, showed crossamplification in B. orbignyanus.

The low values of effective numbers of alleles $(\mathrm{Ne})$ relative to allele richness $(\mathrm{Ra})$ were consistent with the low frequency of some alleles in loci Bh13, BoM5, Borg9, and Borg59. However, according to polymorphic information content (PIC) classification of BOTSTEIN et al. (1980), five of the seven heterologous loci were classified as highly (BoM13) or moderately informative (BoM5, Borg9, Borg13, and Par80). The deviation of HardyWeinberg equilibrium (HW) in the BoM13, Borg9, Borg13, and Par80 loci can be justified by the presence of null alleles, since the presence of the latter can result in an overestimation of homozygotes, leading to an increase in the inbreeding coefficient estimate (ZHIVOTOVSKY et al., 2015). Nonetheless, it should be noted that some loci (BoM5 and Par80) showed heterozygous deficits even without evidence of null alleles. Future studies should be performed to elucidate which evolutionary forces are affecting these populations.

The genetic diversity values estimated by observed (Ho) and expected heterozygosity (He) and number of alleles $(\mathrm{Na})$ indicated that the heterologous primers in the present study can be applied in genetic evaluations of $B$. goulding $i$ populations. Recent population studies in the same genus found similar results of Ho, He (ASHIKAGA et al., 2015) and $\mathrm{Na}$ (SOUZA et al., 2018), thus corroborating the applicability of the primers tested. It is important to emphasize that the lower number of alleles reported in relation to the study performed by ASHIKAGA et al. (2015) can be attributed to factors such as intrinsic genetic characteristics of each species, population structure or different selective pressures in the evaluated regions. FRANKHAM et al. (2008) point out that natural populations are arranged to forces such as mutation, selection, genetic drift and migration that can lead to loss or gain of genetic diversity. In the context of the results of the population analysis, the low values of $\mathrm{Ho}, \mathrm{He}$ and $\mathrm{Na}$ obtained in the present study demonstrated a low genetic diversity in the population of $B$. goulding $i$ in the Araguaia River, and could be caused by one or the set of factors presented above, perhaps intensified by anthropic factors such as overfishing and habitat fragmentation. Studies with larger numbers of samples and collections in different regions of this river are necessary to draw a more complete outlook of the distribution of the genetic diversity in this species.

The cross-amplification of microsatellite markers has again proven to be an excellent tool in genetic studies for fish species for which there are no specific primers. The present research provided for the first time a detailed characterization of the heterologous primers that can be applied in genetic diversity studies of $B$. gouldingi, a species of socioeconomic and environmental importance; although, little has been studied on this subject. These results shall contribute to the conservation management in the wild or captivity of the populations of this species. 


\section{CONCLUSION}

Seven primers designed for $B$. hilarii (Bh13), B. opalinus (BoM5 and BoM13), B. orbignyanus (Borg9, Borg13, and Borg59), and $P$. argenteus (Par80) were used for $B$. gouldingi for the first time. These markers can be useful for testing the genetic diversity and structure of this species.

\section{ACKNOWLEDGEMENTS}

The authors would like to thank the Coordenação de Aperfeiçoamento de Pessoal de Nível Superior (CAPES), Conselho Nacional de Desenvolvimento Científico e Tecnológico (CNPq) and the Programa de Pós Graduação em Ciência Animal (Universidade Estadual de Londrina).

\section{BIOETHICS \\ AND COMMITTEE APPROVAL}

BIOSSECURITY

The methodologies used in this study complied with the ethical principles postulated by the National Council for the Control of Animal Experimentation, and were approved by the Ethics Committee on the use of animals of the State University of Londrina (OF.CIR.99/2017).

\section{DECLARATION OF CONFLICTING INTERESTS}

The authors declare no conflict of interest. The founding sponsors had no role in the design of the study; in the collection, analyses, or interpretation of data; in the writing of the manuscript, and in the decision to publish the results.

\section{AUTHORS' CONTRIBUTIONS}

All authors contributed equally for the conception and writing of the manuscript. All authors critically revised the manuscript and approved of the final version.

\section{REFERENCES}

ABDUL-MUNEER, P. M. Application of microsatellite markers in conservation genetics and fisheries management: recent advances in population structure analysis and conservation strategies. Genetics Research International, v.2014, p.1-11, 2014. Available from: <https://www.hindawi.com/journals/gri/2014/691759/>. Accessed: Mar. 28, 2018. doi: 10.1155/2014/691759.

ALBRECHT, M.P. et al. Population responses of two omnivorous fish species to impoundment of a Brazilian tropical river. Hydrobiologia, v.627, p.181-193, 2009. Available from: <https:// link.springer.com/article/10.1007/s10750-009-9727-7>. Accessed: Mar. 28, 2018. doi: 10.1007/s10750-009-9727-7.

ANTUNES, R.S.P. et al. Molecular characterization and phylogenetic relationships among species of the genus Brycon (Characiformes: Characidae) from four hydrographic basins in Brazil. Genetics and Molecular Research, v.9, p.674684, 2010. Available from: <https://www.ncbi.nlm.nih.gov/ pubmed/20449799>. Accessed: Mar. 28, 2018. doi: 10.4238/ vol9-2gmr759

ASHIKAGA, F.Y. et al. The endangered species Bryconorbignyanus: genetic analysis and definition of priority areas for conservation. Environmental Biology of Fishes, v. 98, p.18451855, 2015. Available from: <http://link.springer.com/ article/10.1007/s10641-015-0402-8>. Accessed: Mar. 20, 2018. doi: 10.1007/s1064101504028.

BARBOSA, A.C.D.R. et al. Thirteen polymorphic microsatellite loci in the Neotropical fish Prochilodus argenteus (Characiformes, Prochilodontidae). Molecular Ecology Resources, v. 6, p. 936938, 2006. Available from: <https://onlinelibrary.wiley.com/doi/ abs/10.1111/j.1471-8286.2006.01406.x. Accessed: Mar. 20, 2018. doi: $10.1111 / \mathrm{j} .1471-8286.2006 .01406 . x>$.

BARBOSA, A.C.D.R. et al. Description of novel microsatellite loci in the Neotropical fish Prochilodus argenteus and crossamplification in $P$. costatus and $P$. lineatus. Genetics and Molecular Biology, v.31, p.357-360. 2008. Available from: $<$ http://www.scielo.br/scielo.php?script $=$ sci arttext\&pid=S141547572008000200032\&ln g=en\&nrm=iso>. Accessed: Mar. 20, 2018. doi: $10.1590 / \mathrm{S} 1415-47572008000200032$.

BARROSO, R.M. et al. Identification and characterization of microsatellites loci in Bryconopalinus (Cuvier, 1819) (Characiforme, Characidae, Bryconiae). Molecular Ecology Notes, v.3, p.297-298, 2003. Available from: <http://onlinelibrary. wiley.com/doi/10.1046/j.1471-8286.2003.00435.x/abstract>. Accessed: Mar. 20, 2018. doi: 10.1046/j.1471-8286.2003.00435.x.

BARROSO, R. M. 2003. Isolamento de microssatélites em Pirapitinga do Sul (Bryconopalinus, Cuvier, 1819) e sua aplicação no estudo populacional da espécie na bacia do Paraíba do Sul. Unpublished. 91 f. Ph.D. Dissertation, Oswaldo Cruz Institute, Rio de Janeiro.

BIGNARDI, A.B. et al. Genetic Variability of Bryconhilarii in a Repopulation Program. Brazilian Archives of Biology and Technology, v.59, 2016. Available from: <http:// www.scielo.br/scielo.php? script $=$ sci_arttext\&pid $=\mathrm{S} 1516$ 89132016000100424\&lng=en\&nrm=iso $>$. Accessed: Mar. 26, 2018. doi: 10.1590/1678-4324-2016160102.

BOTSTEIN, D. et al. Construction of a genetic linkage map in man using restriction fragment length polymorphisms. American Journal of Human Genetics, v.32, p.314-331, 1980 Available from: <https://www.ncbi.nlm.nih.gov/pmc/articles/ PMC1686077/>. Accessed: Mar. 26, 2017.

CALCAGNOTTO, D. et al. Isolation and characterization of microsatellite loci in Piaractusmesopotamicus and their applicability in other Serrasalminae fish. Molecular Ecology Notes, v.1, p.245-247, 2001. Available from: <http://onlinelibrary. wiley.com/wol1/doi/10.1046/j.1471-8278.2001.00091.x/full>. Accessed: Mar. 20, 2018. doi: 10.1046/j.1471-8278.2001.00091.x

CARMO, F.M.S. et al. Optimization of heterologous microsatellites in Piracanjuba. Pesquisa Agropecuária Brasileira, v.50, p.12361239, 2015. Available from: <http://www.scielo.br/scielo. php? pid $=$ S0100-204X2015001201236\&script $=$ sci_arttext $>$. Accessed: Jun. 24, 2018. doi: 10.1590/S0100-204X2015001200015.

CASTRO, P.L. et al. Cross-amplification of heterologous microsatellite markers in Piracanjuba. Ciência Rural, Santa 
Maria, v. 47, e20170374, 2017. Available from: <http:// www.scielo.br/scielo.php?script $=$ sci_arttext\&pid $=\mathrm{S} 0103$ 84782017001200402\&lng=en\&nrm=iso . Accessed: Mar. 25, 2018. doi: $10.1590 / 0103-8478 \mathrm{cr} 20170374$

FAUSTINO, F. et al. Brycongouldingi (Teleostei, Characidae): aspects of the embryonic development in a new fish species with aquaculture potential. Zygote, v.19, p.351-363, 2010. Available from: <https://pdfs.semanticscholar.org/6a4c/0e3a98998b748 3088462ea28e0a9b93d4701.pdf $>$. Accessed: Mar. 2018. doi: $10.1017 / \mathrm{S} 0967199410000535$.

FAUSTINO, F. et al. Morphological and morphometric aspects of early life stages of piabanha Brycongouldingi (Characidae). Journal of Fish Biology, v.86, p.1491-1506, 2015. Available from: <https://www.ncbi.nlm.nih.gov/pubmed/25809317>. Accessed: Mar. 2018. doi: 10.1111/jfb.12652.

FRANKHAM, R. et al. Fundamentos de Genética da Conservação. Riberão Preto: Sociedade Brasileira de Genética, 2008. $280 \mathrm{p}$.

GOUdET J. FSTAT: A Program to Estimate and Test Gene Diversities and Fixation Indices (version 2.9.3.2). 2005. Available from: <https://www2.unil.ch/popgen/softwares/fstat. htm>. Accessed: Mar. 21, 2018.

KALINOWSKI, S.T. et al. Revising how the computer program CERVUS accommodates genotyping error increases success in paternity assignment. Molecular Ecology, v.16, p.1099-1106, 2007. Available from: <http://onlinelibrary.wiley.com/doi/10.1111/ j.1365-294X.2007.03089.x/abstract;jsessionid=A454B71B3BC80 937FFC8D0C9CC42953E.f02t04>. Accessed: Jul. 03, 2017. doi: 10.1111/j.1365-294X.2007.03089.x.

LIMA, F.C.T. Brycongouldingi, a new species from the rio Tocantins drainage, Brazil (Ostariophysi: Characiformes: Characidae), with a key to the species in the basin. Ichthyological Exploration of Freshwaters, v.15, p.279-287, 2004. Available from: $<$ http://www. scielo.br/scielo.php?script=sci_nlinks\&ref $=000116 \&$ pid $=$ S16796225200900030000400017\&lng=pt $>$. Accessed: Mar. 27, 2018.

LIMA, F.C.T. A revision of the cis-andean species of the genus Brycon Müller \&Troschel (Characiformes: Characidae). Zootaxa, v.4222, p.1-89, 2017.Available from: <http://www.mapress.com/j/ zt/issue/view/zootaxa.4222.1>. Accessed: Mar. 28, 2018. doi: 10.11646/zootaxa.4222.1.

LOPERA-BARRERO, N.M. et al. Comparison of DNA extraction protocols of fish fin and larvae samples:modified salt $(\mathrm{NaCl})$ extraction. Ciencia e InvestigaciónAgraria, v.35, p.65-74, 2008. Available from: <http://www.scielo.cl/scielo. php?script=sci_arttext\&pid=S0718-16202008000100008\&lng $=$ es\&nrm=iso $>$. Accessed: Jun. 07, 2016. doi: 10.4067/S071816202008000100008 .

LOPERA-BARRERO, N.M. et al. Cross-amplification of heterologous microsatellite markers in Rhamdiaquelen and Leporinus elongatus. Semina: Ciências Agrárias, v.37, p.517524, 2016a. Available from: $<\mathrm{http}: / / \mathrm{www} \cdot$ uel.br/revistas/uel/index. php/semagrarias/article/view/22603>. Accessed: Mar. 28, 2018. doi: 10.5433/1679-0359.2016v37n1p517.

LOPERA-BARRERO, N.M. et al. Monitoramento e conservação genética de populações naturais de Prochiloduslineatus dos rios Pardo, Mogi-Guaçu e Tietê, São Paulo. Arquivo Brasileiro de
Medicina Veterinária e Zootecnia, v. 68, p. 1621-1628, $2016 \mathrm{~b}$. Available from: $\quad<\mathrm{http}: / / \mathrm{www}$. scielo.br/scielo.php?script=sci arttext\&pid=S0102-09352016000601621\&lng=en\&nrm=iso\&tln $\mathrm{g}=\mathrm{pt}>$. Accessed: Mar. 22 , 2018. doi: 10.1590/1678-4162-8791.

OLIVEIRA, E.J. et al. Origin, evolution and genome distribution of microsatellites. Genetics and Molecular Biology, São Paulo, v.29, n. 2, p.294-307, 2006. Available from <http://www.scielo.br/scielo. php?script $=$ sci_arttext\&pid $=$ S1415-47572006000200018\&ln $\mathrm{g}=$ en\&nrm=iso $>$. Accessed: Mar. 2018. doi: 10.1590/S141547572006000200018 .

PEAKALL, R.; SMOUSE, P.E. GenAlEx 6.5: genetic analysis in Excel. Population genetic software for teaching and research - an update. Bioinformatics, v.28, p.2537-2539, 2012. Available from: $<$ https://www.ncbi.nlm.nih.gov/pmc/articles/PMC3463245/>. Accessed: Mar. 22, 2018. doi: 10.1093/bioinformatics/bts460.

SANCHES, A.; GALETTI, P.M. Microsatellites loci isolated in the fresh water fish Bryconhilarii. Mololecular Ecology Notes, v.6, p.1045-1046, 2006. Available from: <http://onlinelibrary.wiley. com/doi/10.1111/j.1471-8286.2006.01427.x/abstract $>$. Accessed: Mar. 20, 2018. doi: 10.1111/j.1471-8286.2006.01427.x.

SANTOS, M.C.F. et al. Microsatellite markers for the tambaqui (Colossomamacropomum, Serrasalmidae, Characiformes), an economically importanty keystone species of the Amazon River floodplain. Molecular Ecology Resources, v.9, p.874-876, 2009. Available from: <http://onlinelibrary.wiley.com/wol1/doi/10.1111/ j.1755-0998.2008.02331.x/full>. Accessed: Mar. 20, 2018. doi: 10.1111/j.1755-0998.2008.02331.x.

SOUZA, F.P. et al. Novel microsatellite markers for the endangered neotropical fish Bryconorbignyanus and cross-amplification in related species. Italian Journal of Animal Science, p.1-5, 2018. Available from: <https://www.tandfonline.com/doi/full/10 .1080/1828051X.2018.1436008>. Accessed: Mar. 20, 2018. doi: 10.1080/1828051X.2018.1436008.

VAN OOSTERHOUT et al. MICRO-CHECKER: Software for identifying and correcting genotyping errors in microsatellite data. Molecular Ecology Notes, v.4, p.535-538. 2004. Available from: <http://onlinelibrary.wiley.com/doi/10.1111/ j.1471-8286.2004.00684.x/full>. Accessed: Mar. 22, 2018. doi: $10.1111 / \mathrm{j} .1471-8286.2004 .00684$

VIEIRA, M.L.C. et al. Microsatellite markers: what they mean and why they are so useful. Genetics and Molecular Biology, v.39, p.312-328, 2016. Available from: <https://www.ncbi.nlm.nih. gov/pmc/articles/PMC5004837/>. Accessed: Mar. 28, 2018. doi: 10.1590/1678-4685-GMB-2016-0027.

YAZBECK, G.A.; KALAPOTHAKIS, E. Isolation and characterization of microsatellite DNA in the piracema fish Prochiloduslineatus (Characiformes). Genetics and Molecular Research, v.6, p.1026-1034, 2007. Available from: <http://www. funpecrp.com.br /gmr/year2007/vol4-6/GMR339_full_text.htm>. Accessed: Mar. 20, 2018.

ZHIVOTOVSKY, L.A.S.Y. et al. Efficiency of the inbreeding coefficient $f$ and other estimators in detecting null alleles, as revealed by empirical data of locus oke 3 across 65 populations of chum salmon Oncorhynchus keta. Journal of Fish Biology, v. 86 , p. 402-408. Available from: <https://onlinelibrary.wiley. com/doi/abs/10.1111/jfb.12568>. Accessed: Mar. 26, 2018. doi: 10.1111/jfb. 12568 . 